\title{
Communication/Comunicação
}

\section{Rotavirus genotyping in gastroenteritis cases of an infantile population from Western Brazilian Amazonia}

\author{
Genotipagem de rotavírus em casos de gastrenterites de uma população infantil do oeste da \\ Amazônia brasileira
}

\author{
Maria Sandra Moura Costa ${ }^{1}$, Paulo Afonso Nogueira ${ }^{1,2}$, Gleicienne Félix Magalhães ${ }^{1}$, Paula Taquita ${ }^{2}$, \\ Luis André Mariúba ${ }^{2}$, Marilene Penatti ${ }^{3}$ and Patrícia Puccinelli Orlandi ${ }^{1,2}$
}

\begin{abstract}
Introduction: During the period from 2000 to 2002, 79 rotavirus-positive stool samples were collected from children presenting diarrhea in the Western Brazilian Amazon. Methods: Molecular characterization of the G and P genotypes was performed using RT-PCR and electropherotyping analysis by polyacrylamide gel electrophoresis. Results: A total of 59 samples were confirmed as group A rotavirus. A long electrophoretic profile was exhibited by the G1P $[8]$, G3P $[8]$, and G4P $[8]$ genotypes. The G1P $[8]$ genotype was found in greater proportion. The short electropherotype was exhibited only by G2 genotype strains. Conclusions: The proportion of the rotavirus genotypes observed was not different from that in other areas of Brazil. This study is the first genotyping of rotavirus in the Western Brazilian Amazon.
\end{abstract}

Keywords: Group A rotavirus. Genotyping. Brazilian Amazonia.

\section{RESUMO}

Introdução: Entre 2000 e 2002, 79 amostras positivas para rotavírus foram coletadas de crianças com diarreia na Amazônia ocidental brasileira. Métodos: Para a caracterização molecular dos genótipos G e P foram realizadas as reações de RT-PCR e a análise dos eletroferotipos por eletroforese em gel de poliacrilamida (PAGE). Resultados: 59 amostras foram confirmadas como pertencentes ao rotavírus grupo $\mathrm{A}$. Os genótipos G1P [8], G3P[8] e G4P[8] apresentaram perfis eletroforéticos longos. O genótipo G1P $[8]$ foi encontrado em maior proporção. O eletroferotipo curto ocorreu apenas em genótipos G2. Conclusões: A proporção dos genótipos de rotavírus observada não foi diferente de outras áreas do Brasil. Este estudo é a primeira genotipagem de rotavírus na Amazônia ocidental brasileira.

Palavras-chaves: Rotavírus grupo A. Genotipagem. Amazônia brasileira.

Rotavirus is the main cause of acute gastroenteritis in children under five years old worldwide. It is estimated that 130 million children are infected with rotavirus gastroenteritis, causing 2 to 4 million hospital admissions and 600,000 deaths every year ${ }^{1}$.

Rotavirus belongs to the Reoviridae family, and the capsid is made of a triple protein layer. The genome is composed of eleven segments of double-stranded RNA, and each segment encodes for a specific protein. Two proteins that make up the outer capsid of the virion, the VP7 (glycoprotein) and the VP4 (protease-sensitive), are

1. Setor de Microbiologia, Centro de Pesquisa em Medicina Tropical, Porto Velho, RO. 2. Centro de Pesquisa Leônidas e Maria Deane, Fundação Oswaldo Cruz, Manaus, AM. 3. Direção de Pediatria, Hospital Infantil Cosme Damião, Porto Velho, RO.

Address to: Dra. Patrícia Puccinelli Orlandi. Rua Terezina 476, Adranópolis, 69057-070 Manaus, AM, Brasil.

Phone: 5592 3621-2333

e-mail: patrícia_orlandi@amazonia.fiocruz.br

Received in $16 / 12 / 2010$

Accepted in 17/05/2011 important for the genetic diversity of rotaviruses. The VP7 or VP4 antigens are used to classify $\mathrm{G}$ and $\mathrm{P}$ genotypes, respectively. In the host, both proteins induce neutralizing antibodies, which are essential for protection against rotavirus infections ${ }^{2}$.

On the basis of antigenic and genetic diversities, $23 \mathrm{G}$ and $30 \mathrm{P}$ rotavirus types have been identified among strains of both human and animal origin, the serotypes G1 to G4 being the most common cause of disease worldwide ${ }^{3}$. Ten G types and 11 P types (mostly, G1-G6, G8-G10, and G12, and $\mathrm{P}[4], \mathrm{P}[6], \mathrm{P}[8]$, and $\mathrm{P}[9]$, respectively) have been recovered in association with human infections. The combinations G1P [8], G2P [4], G3P [8], and G9P [8] are the most frequently found $d^{3-4}$.

Recently, a study on the etiology of gastroenteritis in the infantile population showed group A rotavirus to be the most frequent enteropathogen, occurring in $23.6 \%$ of the total diarrhea cases; the second group consisted entirely of pathogenic categories of diarrheogenic Escherichia coli differentiated by PCR technique, occurring in $18.2 \%$ of cases, followed by Salmonella sp. (9.3\%), Adenovirus (6.3\%), and Shigella sp. (5.1\%).

This study aimed to characterize $\mathrm{G}$ and $\mathrm{P}$ genotypes infecting an infantile population admitted with viral gastroenteritis and to extend our knowledge of rotavirus infection in individuals from Western Brazilian Amazonia.

From March 2000 to March 2002, 330 stool samples were collected from diarrheic children presenting acute gastroenteritis at the Cosme Damião Infantile Hospital, located in downtown Porto Velho, the capital of the State of Rondonia, Brazil. The hospital admits children from the periphery of the city. The stool samples were collected from children after consent was given by their parents or other legal guardians, through written signature. This study received approval from the committee on ethics (Center of Tropical Medicine Ethical Committee - Porto Velho, number 463). The rotavirus was diagnosed through two tests. First, the samples were analyzed using the commercial kit Virotec Rota (Omega Diagnostics, Scotland, United Kingdom), which uses latex particle agglutination. Samples were then confirmed by a combined Enzyme Immunoassay for Rotavirus and Adenovirus (EIARA Biomanguinhos/Oswaldo Cruz Foundation, Healthy Ministerial of Brazil).

The rotavirus-positive stool samples were dissolved in $0.01 \mathrm{M}$ Tris- $\mathrm{HCl}-\mathrm{CaCl}$ ( $\mathrm{pH} 7.2$ ) and clarified by centrifugation at $800 \mathrm{~g}$, and the supernatants were frozen at $-20^{\circ} \mathrm{C}$. The viral RNA was extracted as described by Boom et al. ${ }^{6}$, followed by separation by polyacrylamide gel electrophoresis (PAGE) 7 . The segments of double-stranded RNA (dsRNA) were visualized after silver nitrate staining ${ }^{7}$. 
The reverse transcriptase reaction and PCR were performed as described by Das et al. ${ }^{8}$ and Gentsch et al. ${ }^{9}$, respectively. For G genotypes, the first PCR was performed using the consensus primer pair $9 \operatorname{con} 1 / 9 \operatorname{con} 2$. In this reaction, one fragment of $904 \mathrm{bp}$ was amplified, and the product was submitted to the nested reaction, the combination between primers $9 \operatorname{con} 1$ and a pool of G-specific primers, 9TI-1, 9T1-2, 9T-3P, 9T-4, and 9T-9B genotypes for variable regions of the VP7 gene, specifically to G1, G2, G3, G4, and G98. For $\mathrm{P}$ genotypes, the first PCR was performed using the consensus primer pair con2/con3; one fragment of $876 \mathrm{bp}$ was amplified. In the nested reaction, the combinations were between con 3 primer and the pool of P-specific primers for variable regions of the VP4 gene, 1T-1, $2 \mathrm{~T}-1,3 \mathrm{~T}-1$, and $4 \mathrm{~T}-1$, specifically to the $\mathrm{P}[8], \mathrm{P}[4], \mathrm{P}[6]$, and $\mathrm{P}[9]$ genotypes ${ }^{9}$. The products were visualized under UV in $1 \%$ agarose gels stained with ethidium bromide.

Of 79 rotavirus-positive stool samples collected, $75 \%$ gave PAGE results positive for group A rotavirus. The most frequent profile was the long PAGE profile that was observed in $74.5 \%$ (44/59) of the samples. The 15 remaining samples presented the short PAGE profile (Figure 1).

When the $\mathrm{G}$ and $\mathrm{P}$ genotyping results were combined, the most frequent genotypes observed were identified as G1P[8], G2P[4], G3P $[8]$, and G4P $[8]$ (Table 1), the G1P $[8]$ genotype being the most common, found in $61 \%$ of samples; this was followed by G2P [4] in $20 \%, \mathrm{G} 3 \mathrm{P}$ [8] in $6.7 \%$, and G4P [8] in $3.3 \%$. Some samples with $\mathrm{G} 1$ and $\mathrm{G} 2$ genotypes did not have had their P genotype identified; these represented $3.3 \%$ and $5 \%$ of the samples, respectively. All short profiles were G2P[4] genotypes. We did not find an occurrence of mixed genotypes in our samples.

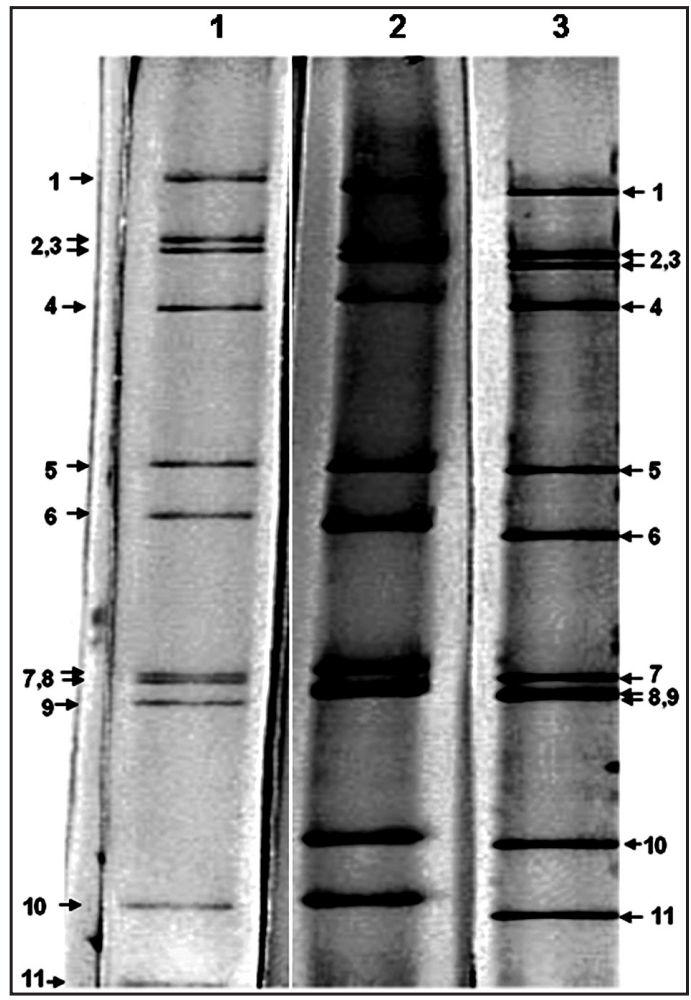

FIGURE 1 - A rotavirus PAGE profile before the introduction Rotarix in the Brazilian Expanded Immunization Program.

Running of dsRNA from typical group A rotavirus isolated from the stool of children with different PAGE results. Column 1 shows the long profile, columns 2 and 3 the short profile.

PAGE: polyacrylamide gel electrophoresis.
TABLE 1 - $G$ and $P$ rotavirus genotypes found in an infantile population from Porto Velho, Rondonia, presenting viral gastroenteritis.

\begin{tabular}{lrrrrr}
\hline & G1 & G2 & G3 & G4 & Total \\
\hline $\mathrm{P}[4]$ & 0 & 12 & 0 & 0 & 12 \\
\hline $\mathrm{P}[8]$ & 36 & 0 & 4 & 2 & 42 \\
\hline Not typed & 2 & 3 & - & - & 5 \\
\hline Total & $\mathbf{3 8}$ & $\mathbf{1 5}$ & $\mathbf{4}$ & $\mathbf{2}$ & $\mathbf{5 9}$ \\
\hline
\end{tabular}

Studies carried out by our group with populations of ambulatory or hospitalized children in Porto Velho, State of Rondonia, showed rotavirus as the main cause of gastroenteritis, occurring in $23.6 \%$ of the total diarrhea cases ${ }^{5,10}$.

In the current study, the PAGE profiles of stool samples from children in Porto Velho revealed both long and short migration profiles. Luz et al. ${ }^{11}$, in a study comprising most rotavirus strains of serotypes G1, G3, G4, and G9, showed a predominance of rotavirus strains with long electropherotype. In fact, this electropherotype profile was observed in $74 \%$ of our samples. Rotavirus strains displaying short electropherotype represented $25.5 \%$ of total and are usually associated with G2 serotypes ${ }^{12}$, which was confirmed in this study.

On the basis of the current binary system for rotavirus characterization, the majority of isolates from diarrheic children fall into four groups: $\mathrm{G} 1 \mathrm{P}[8], \mathrm{G} 2 \mathrm{P}[4], \mathrm{G} 3 \mathrm{P}[8]$, and G4P $[8]$. Among the rotavirus genotypes observed, the $\mathrm{G} 1 \mathrm{P}[8]$ and $\mathrm{G} 2 \mathrm{P}[4]$ rotavirus strains were the most prevalent - which is not different from the worldwide trend - in 26 years of monitoring in areas of Brazil ${ }^{13}$.

The stool samples used in this study were collected before the introduction of the combined live and attenuated G1P [8] group A rotavirus vaccine Rotarix by the Brazilian Expanded Immunization Program. G2P [4] genotypes were prevalent in our study, with a proportion very similar to that in the pre-vaccination era (before 2005), as reported by Leite and colleagues ${ }^{13}$.

Interestingly, in Brazil as a whole, the reemergence of the $\mathrm{G} 2 \mathrm{P}[4]$ or $\mathrm{G} 2 \mathrm{P}[\mathrm{NT}]$ genotypes has been remarkable during the last few years, and it seems to reflect a continental phenomenon. High incidence of the G2P [4] genotype has been reported in El Salvador, Guatemala, and Honduras ${ }^{14}$. However, the resurgence of $\mathrm{G} 2 \mathrm{P}[4]$ in neighboring countries happened before the introduction of Rotarix vaccination into the public sector, and in the case of Brazil the increase of $\mathrm{G} 2 \mathrm{P}[4]$ occurred prior to the implementation of Rotarix vaccination.

On the other hand, according to Leite et al. ${ }^{13}$ a significant predominance of $\mathrm{G} 2 \mathrm{P}[4]$ and $\mathrm{G} 2 \mathrm{P}[\mathrm{NT}]$ strains following the introduction of the Rotarix vaccine in Brazil has been observed. As efficacy in the protection achieved against the fully heterotypic G2P [4] immunization was low, there is growing concern for regarding the lower protection against $\mathrm{G} 2 \mathrm{P}[4]$ group A rotavirus of vaccinated children. Therefore, only continuous monitoring of rotavirus disease burden and genotype surveillance will provide this information.

We did not find an occurrence of mixed genotypes in our samples as shown by other studies ${ }^{4,8,15}$. Additionally, the newly emergent G9 genotype was still not present in this area in 2002, when the collection was performed. It may be noticed that from 1997 to 1999 , the G9, the $5^{\text {th }}$ most epidemiologically important serotype, was not yet identified in São Luis, Brazil, as it has only recently emerged worldwide ${ }^{13}$. 
Extensive and continuous monitoring of rotavirus disease burden and surveillance studies are necessary to assess the question that emerges regarding the early post-vaccination era, that is, whether the monovalent rotavirus A vaccine will contribute to additional changes in genotype distribution in the Western Brazilian Amazon and nationwide.

In conclusion, our study provides relevant data about the first genotyping of rotavirus from children in the Western Brazilian Amazon and about epidemiological surveillance of rotaviruses. The results of our study should help future investigations into the genotypes that circulate after the introduction of the vaccine against rotavirus in Brazil.

\section{CONFLICT OF INTEREST}

The authors declare that there is no conflict of interest.

\section{REFERENCES}

1. Grimwood K, Buttery JP. Clinical update: rotavirus gastroenteritis and its prevention. Lancet 2007; 370:302-304.

2. Estes MK, Kapikian AZ. Rotaviruses. In: Knipe DM, Howley PM, editors. Fields Virology. $5^{\text {th }}$ ed. Lippincott: Williams \& Wilkins; 2007. p. 1917-1974.

3. Ursu K, Kisfali P, Rigo D, Ivanics E, Erdelyi K, Dan A, et al. Molecular analysis of the VP7 gene of pheasant rotaviruses identifies a new genotype, designated G23. Arch Virol 2009; 154:1365-1369.

4. Soares LS, Mascarenhas JDP, Gabbay YB, Gusmão RHP, Linhares AC. Molecular characterization of G1 human rotaviruses detected in children from Belém, Pará, Brazil. Rev Pan-Amaz Saude 2010; 1:125-130.

5. Orlandi PP, Magalhães GF, Matos NB, Silva T, Penatti M, Nogueira PA, et al. Etiology of diarheal infections in children of Porto Velho (Rondônia, Western Amazon region, Brazil). Braz J Med Biol Res 2006; 39:507-517.
6. Boom R, Sol CJ, Salimans MM, Jansen CL, Wertheim-van Dillen PM, van der Noordaa J. Rapid and simple method for purification of nucleic acid. J Clin Microbiol 1990; 28:495-503.

7. Pereira HG, Azeredo RS, Leite JP, Barth OM, Sutmoller F, Farias V, et al. Comparison of polyacrylamide gel electrophoresis (PAGE), immunoelectron microscopy (IEM) and enzyme immunoassay (EIA) for the rapid diagnosis of rotavirus infection in children. Mem Inst Oswaldo Cruz 1983; 78:483-490

8. Das S, Sen A, Uma G, Varghese V, Chaudhuri S, Bhattacharya SK, et al. Genomic diversity of group A rotavirus strains infecting humans in eastern India. J Clin Microbiol 2002; 40:146-149.

9. Gentsch JR, Glass RI, Woods P, Gouvea V, Gorziglia M, Flores J, et al. Identification of group A rotavirus gene 4 types by polymerase chain reaction. J Clin Microbiol 1992; 30: 365-1373.

10. Magalhães GF, Nogueira PA, Grava AF, Penati M, Silva LH, Orlandi PP. Rotavirus and adenovirus in Rondônia. Mem Inst Oswaldo Cruz 2007; 102: 555-557.

11. Luz CRN, Mascarenhas JDP, Gabay BY, Motta ARB, Lima RVT, Soares LS, et al. Rotavirus serotype and electropherotypes identified among hospitalized children in São Luis, Maranhão, Brazil. Inst Med Trop S Paulo 2005; 47: 287-293.

12. Mascarenhas JDP, Linhares AC, Gabbay YB, Leite JPG Detection and Characterization of rotavirus G and P Types from Children Participating in a rotavirus Vaccine Trial in Belem, Brazil. Mem Inst Oswaldo Cruz 2002; 97:113-117.

13. Leite JPG, Carvalho-Costa FA, Linhares AC. Group A rotavirus genotypes and the ongoing Brazilian experience - A Review. Mem Inst Oswaldo Cruz 2008 ; $103: 745-753$

14. Patel MM, Oliveira LH, Bispo AM, Gentsch J, Parashar UD. Rotavirus P[4]G2 in a vaccinated population, Brazil. Emerg Infect Dis 2008; 14:863.

15. Santos N, Hoshino Y. Global distribution of rotavirus serotypes-genotypes and its implication for the development and implementation of an effective rotavirus vaccine. Rev Med Virol 2005; 15:29-56. 